\title{
Effect of non-genetic factors on First Lactation 305 days and Lifetime Milk Yield in Sahiwal cattle
}

\author{
Manjari Pandey, Raja KN, Saleem Yousuf and AK Gupta
}

Received: 02 December 2018 / Accepted: 26 December 2018 / Published online: 21 February 2019

(C) Indian Dairy Association (India) 2019

\begin{abstract}
The present research was carried out to determine the effect of non-genetic factors on first lactation 305 days and lifetime milk yield of Sahiwal cattle. Data were collected on 392 cows maintained at NDRI, Karnal herd for first lactation 305 days milk yield and on 282 cows for lifetime production, over a period of 31 years (1986-2017). The traits were subjected to least squares analysis using Harvey (model 1) considering season of calving, period of calving and age at first calving as fixed effects. The overall least squares mean for first lactation 305 days milk yield and lifetime milk yield were found to be $1898.95 \pm 50.26$ and 7241.47 $\pm 411.18 \mathrm{Kg}$ respectively. The effect of season of calving and age at first calving was found to be non- significant on first lactation 305 days milk yield whereas the effect of period of calving was significantly affecting first lactation 305 days milk yield. The effect of season of calving was non-significant on lifetime milk yield also. Age at first calving and period of calving had a highly significant effect on life time milk yield of Sahiwal cattle. Hence, the data needs to be adjusted for all the significant non-genetic factors so that the data may be used further for genetic analysis.
\end{abstract}

Manjari Pandey $(\bowtie)$

AGB Division, Indian Veterinary Research Institute, Izatnagar, Bareilly, U.P-243122, India.

E-mail: mnpandey155@gmail.com

Raja K N

AG\&B Division, ICAR- National Bureau of Animal Genetic Resources, Karnal, Haryana - 132001

E-mail: drknraja@gmail.com

Saleem Yousuf

AG\&B Division, ICAR-National Dairy Research Institute, Karnal, Haryana -132001 , India

E-mail: saleemyousuf57155@gmail.com

A K Gupta

AG\&B Division, ICAR-National Dairy Research Institute, Karnal,

Haryana -132001 , India

E-mail: guptaak2009@gmail.com
Keywords:Non-genetic factors, First lactation 305 day milk yield, Lifetime milk yield, Indigenous, Sahiwal cattle

\section{Introduction}

India has diverse livestock population which provides employment to about $8.8 \%$ of the human population and livelihood to about two-third of rural community. As per $19^{\text {th }}$ livestock census, India has 190.9 million cattle. The number of indigenous cattle has decreased over the years in spite of having many advantageous characteristics like resistance to heat and tropical diseases, higher feed conversion efficiency, better adaptability to tropical conditions etc.

Sahiwal is one such best indigenous dairy breed which produces the highest milk among all zebu breeds. Pure Sahiwal herds are available around Fazilka and Abohar towns of Ferozepur district in Punjab, Sri Ganganagar district of Rajasthan and some pockets of U.P. and Chattisgarh. Further improvement of traits like first lactation 305 days milk yield and lifetime milk yield of Sahiwal is possible. The various factors affecting these traits need to be analyzed. The phenotypic data collected on production are a combined effect of genetic and environmental factors and are not a true measure of the genetic worth of the animal. Hence, before using this data for genetic evaluation of the animal, it needs to be adjusted. In the present investigation the effect of various non-genetic factors affecting the first lactation 305 days milk yield and lifetime milk production are analyzed using least square analysis.

\section{Materials and methods}

\section{Data collection}

The data for the present investigation was collected from the history sheets and daily milk record registers of Sahiwal cattle maintained at ICAR - National Dairy Research Institute (NDRI), Karnal, Haryana. The first, second, third, fourth, fifth and sixth lactation production records of Sahiwal over a period of 31 years (1986-2017) were recorded. 
NDRI livestock farm is located at an altitude of 250 meters above the mean sea level in the Indo-gangetic alluvial plains on $29^{\circ} 42^{\prime} \mathrm{N}$ latitude and $72^{\circ} 02^{\prime} \mathrm{E}$ longitude. The temperature ranges from $0^{\circ} \mathrm{C}$ in winter months to $45^{\circ} \mathrm{C}$ in summer months. The annual rainfall is about 760 to $960 \mathrm{~mm}$. The relative humidity ranges from $41 \%$ to $85 \%$. Thus, it is obvious that the Sahiwal cattle maintained in the farm get exposed to extreme climatic conditions.

\section{Statistical analysis}

The present study was done with the objective of analyzing the effect of non genetic factors on first lactation 305 days milk yield and life time milk yield in Sahiwal cattle. For first lactation 305 days milk yield the performance record of 392 cattle and for lifetime milk yield record of 292 cattle were recorded, spread over a period of 31 years (1986-2017). The following fixed model was used to analyze the unequal and non-orthogonal data via least square analysis

$$
\mathrm{Y}_{\mathrm{ijkl}}=\mu+\mathrm{S}_{\mathrm{i}}+\mathrm{P}_{\mathrm{j}}+\mathrm{A}_{\mathrm{k}}+\mathrm{e}_{\mathrm{ijkl}}
$$

Where,

$$
\begin{gathered}
\mathrm{Y}_{\mathrm{ijk} \mathrm{k}}=\text { observation on } \mathrm{l}^{\text {th }} \text { individual belonging } \mathrm{k}^{\text {th }} \text { age group } \\
\text { in } \mathrm{j}^{\text {th }} \text { period and } \mathrm{i}^{\text {th }} \text { season of calving; }
\end{gathered}
$$

$\mu \quad=$ is the overall population mean;

$\mathrm{S}_{\mathrm{i}} \quad$ fixed effect of $\mathrm{i}^{\text {th }}$ season of calving;

$P_{j} \quad=$ fixed effect of $j^{\text {th }}$ period of calving;

$A_{k}=$ fixed effect of $k^{\text {th }}$ age group;

$\mathrm{e}_{\mathrm{ijk}}=$ is the random error associated with each observation which is assumed to be normally and independently distributed with mean zero and variance $o_{e}^{2}$.

The classification of season of calving was done as follows; $\mathrm{S}_{1}=$ winter (December to March), $\mathrm{S}_{2}=$ summer (April to June), $\mathrm{S}_{3}=$ rainy (July to August), $\mathrm{S}_{4}=$ autumn (September to November). For classification of period of calving, the total span of 31 years was divided into ten periods (P1 to P10) of three consecutive years with last period having 4 consecutive years. The age at first calving was coded as A1 de 961 days to A7 ee1367 days with a class interval of 80 days.

The traits considered in the study were first lactation 305 days milk yield and life time milk yield. Lifetime was defined as the parity after which the milk production no longer remained

\begin{tabular}{|c|c|c|c|c|}
\hline Source & Code & No. of observations & FL305DMY(Kg) & $\operatorname{LTMY}(\mathrm{Kg})$ \\
\hline Overall mean & $\mu$ & 392 & $1898.95 \pm 50.26$ & $7241.47 \pm 411.18$ \\
\hline \multirow[t]{3}{*}{ Season of calving } & $\mathrm{S}_{1}$ & 181 & $1851.36 \pm 54.58$ & $7677.72 \pm 406.90$ \\
\hline & $\mathrm{S}_{2}$ & 135 & $1770.46 \pm 58.79$ & $6900.88 \pm 418.99$ \\
\hline & $\mathrm{S}_{4}$ & 19 & $1998.84 \pm 149.21$ & $7196.80 \pm 829.73$ \\
\hline \multirow[t]{6}{*}{ Period of calving } & $\mathrm{P}_{1}^{4}$ & 19 & $2086.05 \pm 152.82^{\mathrm{e}}$ & $8481.27 \pm 861.25^{\mathrm{e}}$ \\
\hline & $\mathrm{P}_{4}$ & 31 & $1750.74 \pm 120.25^{\mathrm{b}}$ & $5785.22 \pm 595.85^{\mathrm{a}}$ \\
\hline & $\mathrm{P}_{5}^{4}$ & 23 & $1521.31 \pm 137.11^{\mathrm{a}}$ & $6090.69 \pm 694.70^{\mathrm{ab}}$ \\
\hline & $\mathrm{P}_{6}$ & 35 & $1600.84 \pm 115.22^{\mathrm{a}}$ & $6972.67 \pm 573.59^{c}$ \\
\hline & $\mathrm{P}_{7}^{0}$ & 76 & $1844.60 \pm 80.28^{c}$ & $7394.56 \pm 482.56^{\mathrm{d}}$ \\
\hline & $\mathrm{P}_{8}$ & 58 & $1695.57 \pm 87.96^{\mathrm{b}}$ & $6279.82 \pm 493.82^{\mathrm{b}}$ \\
\hline \multirow{6}{*}{ AFC Group } & $\mathrm{A}_{2}$ & 68 & $1796.15 \pm 88.24$ & $8014.26 \pm 399.58^{d}$ \\
\hline & $\mathrm{A}_{3}$ & 123 & $1930.58 \pm 69.12$ & $7887.30 \pm 389.80^{\mathrm{d}}$ \\
\hline & $\mathrm{A}_{4}$ & 73 & $1984.80 \pm 84.71$ & $8797.92 \pm 565.88^{\mathrm{e}}$ \\
\hline & $\mathrm{A}_{5}$ & 40 & $2011.25 \pm 101.67$ & $5510.43 \pm 331.24^{\mathrm{a}}$ \\
\hline & $\mathrm{A}_{6}$ & 23 & $1871.61 \pm 136.11$ & $6242.31 \pm 1847.14^{\mathrm{b}}$ \\
\hline & $\mathrm{A}_{7}$ & 31 & $2044.65 \pm 119.12$ & $6322.82 \pm 448.16^{\mathrm{b}}$ \\
\hline
\end{tabular}
profitable and also the number of animals reaching the next parity

Table1 Least squares mean and standard error of first lactation 305 days milk yield and lifetime milk yield in Sahiwal cattle

significant $(\mathrm{P}<0.01$ and $\mathrm{p}<0.05)$ difference of means. 
decreased to a significantly low level. Thus, lifetime milk yield was calculated only for those cows that completed their $4^{\text {th }}$ lactation. Least-squares and maximum likelihood computer program of Harvey (1990) was used for carrying out the analysis.

\section{Results and discussion}

\section{Overall performance}

The overall least square mean of FL305DMY was found to be $1898.95 \pm 50.26 \mathrm{Kg}$ (Table1) which was similar to the earlier reports of Dongre (2012) and Manoj (2012). However the estimate was lower as compared to that reported by Sundaresan et al. (1965), Singh et al. (2005) and it was higher than that reported by Raja and Narula (2007), Rehman et al. (2008).

The least square mean of lifetime milk yield was found to be $7241.47 \pm 411.18 \mathrm{Kg}$ (Table2). The estimate was higher than that reported by Deulkar and Kothekar (1999) i.e. $4246.68 \pm 224.84 \mathrm{Kg}$ He had also taken the life time milk yield up to fourth parity in Sahiwal cattle.

\section{Effect of season of calving}

The effect of season of calving on first lactation 305 days milk yield was found to be non significant. Similar observation was reported by Nagpal and Acharya (1971), Kannan and Gandhi (2004), Debbarma et al. (2010), Dongre (2012).

Season of calving had a non-significant effect on the lifetime milk yield also. However, Gandhi and Gurnani (1990) observed significant influence of season of first calving on lifetime milk yield in Sahiwal cattle. The non significant influence may be due to better management practices throughout the year in all seasons and also because Sahiwal can adapt better to the local climatic conditions.

\section{Effect of period of calving}

The effect of period of calving on first lactation 305 days milk yield was highly significant. The effect was also reported significant by Nagpal and Acharya (1971), Taneja and Sikka (1981), Yadav et al. (1992), Dongre (2012).

Similar to the first lactation 305 days milk yield, the lifetime milk yield was also found to be highly affected by the period of first calving. Significant influence of period of first calving on lifetime milk yield in Sahiwal cattle was reported by Acharya and Nagpal (1971),Hegde and Bhatnagar (1985), Gandhi and Gurnani (1995), Pundir and Raheja (1997), Kumar (2003) and Kannan (2004). The significant effect indicated the change in manage mental practices and the environmental changes during these periods which caused the variations in first lactation 305 days and lifetime milk yield

\section{Effect of age at first calving group on FL305DMY}

The first lactation 305 days milk yield was not significantly influenced by age at first calving. Similar result was reported by Dongre (2012). However its effect was reported as significant by Debbarma et.al. (2010).

Unlike the effect of age at first calving on first lactation 305 days milk yield, its effect on the lifetime milk yield was found to be highly significant. The maximum lifetime milk yield was observed from the cows that fall in the age group $\mathrm{A}_{4}$ (1124-1204 days) while the minimum lifetime milk yield was observed in cows that fall in age group $\mathrm{A}_{5}$ (1205-1285 days).

\section{Conclusions}

The least squares mean of first lactation 305 days milk yield and lifetime milk yield was found to be $1898.95 \pm 50.26 \mathrm{Kg}$ and 7241.47 $\pm 411.18 \mathrm{Kg}$ respectively. The season of calving had nonsignificant effect on FL305DMY and LTMY whereas the effect of period of calving was found to be highly significant on FL305DMY and LTMY. The AFC had non-significant effect on first lactation 305 days milk yield but had significant effect on lifetime milk yield in Sahiwal. Trend followed by the first lactation 305 days milk yield and lifetime milk yield during the different periods can be generalized as phases where first they increased then decreased and then again increased. However the increase in later periods was less than that of the earlier period performance (up to period 3). The decrease in the performance in the middle periods may be due to increased focus given to cross breeding as compared to the improvement of indigenous cattle. As of now again the performance is improving but still it is a long way to fully improve and utilize the true characteristics of Sahiwal cattle. Hence continuous effort in genetic improvement and conservation of Sahiwal breed is recommended through selection and proper breeding plan.

\section{References}

Debbarma M, Gandhi RS, Raja TV, Singh A, Sachdeva GK (2010) Influence of certain non-genetic factors on test day milk records in Sahiwal cattle. Indian J Dairy Sci 63(6): 504-506

Deulkar PB, Kothekar MD (1999) Sire evaluation considering first lactation yield for improvement of lifetime production in Sahiwal. Indian J Anim Sci 69 (4): 240-242

Dongre VB, Gandhi RS, Singh A, Sachdeva GK, Singh RK, Gupta A (2013) Influence of non-genetic factors on fortnightly test day milk yields and first lactation 305-day milk yield in sahiwal cattle. Indian J Ani Res 47:181-183

Gandhi RS, Gurnani M (1990) Breeding efficiency and producing ability as contrasting traits in Sahiwal cows. Indian J Ani Sci 60: 482-485

Gandhi RS and Gurnani M (1995) Lactation-wise heritabilities of some economic traits in Sahiwal cattle. Indian J Dairy Sci 48 (1):75-77

Harvey WR (1990) Mixed Model Least squares and Maximum Likelihood computer Program (LSMLMW). PC-1 version

Hegde M, Bhatnagar DS (1985) Lifetime performance of different genetic groups of Brown Swiss crossbred cows. Indian J Dairy Sci 38 (4): $321-325$ 
Kannan DS, Gandhi RS (2004) Influence of non-genetic factors on life time traits in Sahiwal cattle. Indian J Dairy Sci 57(3): 185-187

Manoj M, Gandhi RS, Raja TV, Singh A, Sachdeva GK (2012) Effect of Non Genetic Factors on First Lactation Production and Reproduction Performance in Sahiwal Cattle.

Indian J Dairy Sci 65(3): 264-265

Nagpal MP, Acharya RM (1971) Studies on Sahiwal dairy herd records: Effect of non-genetic factors. Indian J Anim Sci 41(7): 515-520

Pundir RK, Raheja KL (1997) Genetic parameters estimation for first lactation and lifetime traits in Sahiwal and Hariana using multi trait maximum likelihood. Indian J Dairy Sci 50 (5):359-366

Raja KN, Narula HK (2007) Effects of non-genetic factors on production traits of Sahiwal cattle. Indian Vet J 84(4): 374-376
Rehman ZU, Khan SM, Bhatti SA, Iqbal J. (2008) Factors affecting first lactation performance of Sahiwal cattle in Pakistan. Arch Tierz. Dummerstorf 51 (4): 305-317

Singh VK, Singh CV, Kumar D, Kumar A (2005) Genetic evaluation of some economic traits in Sahiwal and its crossbreds. Indian J Dairy Sci 58: 206-210

Sundaresan D, Ray SN, Iya KK (1965) The performance of the dairy herds at the National Dairy Research Institute, Karnal. Indian J Dairy Sci. 18(1): 34-44

Taneja VK, Sikka AK (1981) Factors affecting some economic traits in Indian dairy breeds. Indian J Dairy Sci 34(3): 347-349

Yadav AS, Rathi SS, Dahiya SP, Arora DN (1992). Factors affecting some performance traits in Sahiwal cattle. Indian J Dairy Sci 45(10): 522527 